\title{
Teacher Quality in the Light of the Philippine Professional Standards for Teachers
}

\author{
${ }^{1}$ Johnny Roberto \\ ${ }^{2}$ Dennis V. Madrigal \\ ${ }^{1}$ Pandan Bay Institute, Antique, Philippines \\ ${ }^{2}$ University of Negros Occidental-Recoletos, Bacolod City, Philippines \\ jrobertz_pbi@yahoo.com.ph
}

\begin{abstract}
The paper aimed to assess the respondents' level of teaching standards competence using the Philippine Professional Standards for Teachers (PPST) and their performance using the school's Teacher Performance Evaluation, respectively. Likewise, it purported to determine the significant difference in the level of teaching standards competence and performance of teachers when teachers were grouped according to sex, marital status, educational attainment, and status of employment. The respondents were the whole population of the basic education department of a diocesan school in Antique composed of 33 teachers. Using a descriptive-comparative and correlational research design, the standardized questionnaires on teaching standards competence using PPST and teaching performance using teacher performance evaluation of the diocesan school were utilized to gather the data. Descriptive and inferential analyses using the mean, Mann Whitney $U$ and Independent Samples t-test, and the Pearson Product Moment of Correlation were utilized to analyze the data. The findings revealed that the level of teaching standards competence and performance of basic education teachers as assessed by the principals and teachers themselves were proficient and satisfactory, respectively. Moreover, the findings further showed no significant difference in both the teaching standards competence and performance when the teachers were grouped according to sex, educational attainment, marital status, and status of employment. However, the overall findings revealed that there is a significant relationship between the level of teaching standards competence and performance.
\end{abstract}

Keywords: Education, Philippine Professional Standards for Teachers, Teaching Standards Competence, Teaching Performance

Date Submitted: November 25, 2018

Date Revised: February 25, 2019 


\subsection{Introduction}

The 21st century teaching focuses on teaching standards or standards of teaching practice (Beck et al., 2002; CEPPE, 2013) which define what teachers and school leaders should be able to do (Chung \& Kim, 2010; CEPPE, 2013). Therefore, teachers are placed at the center of the school in the teaching standards (Beck, et al., 2002). Moreover, teaching quality is widely recognized as the single most important factor affecting student learning outcomes (CEPPE, 2013). Hence, the attributes of highly effective teaching must be aimed to produce a common point of reference for effective practice in teaching and learning (Rasool, et al., 2017).

In the Philippines, the $\mathrm{K}$ to 12 Basic Education Curriculum was launched in 2012 (D. O. No. 31, 2012). This major change has consistently pursued teacher quality reforms. The Philippine Professional Standards for Teachers (PPST) formerly the National Competency-Based Teacher Standards (NCBTS) (D. O. No. 32, 2009) was established as a framework of teacher quality (D. O. No. 42, 2017). In view of this study, the question on the practicability and effectiveness of PPST as a response to the 21st century learning shall be used as a ground or basis whether teachers employed in the private schools also observe and maintain the same standards. Relatedly, Pandan Bay Institute, a Catholic diocesan school, has experienced a great challenge regarding faculty retention and faculty turnover that make the quality of education become an issue. To address this concern, the diocesan school annually administers its Teacher Performance Evaluation instrument as a quality standard system to sustain teacher quality.

The paper intended to assess the level of teaching standards competence of basic education teachers in the areas of content knowledge and pedagogy, learning environment, diversity of learners, curriculum and planning, assessment and reporting, community linkages and professional engagement, and personal growth and professional development as assessed by the principals and teachers themselves when they are taken as a whole and when they are grouped according to demographic variables such as sex, marital status, educational attainment, and status of employment. Moreover, it investigated teachers' level of performance in terms of teaching competence, administrative compliance, personal, social, and professional competence, and service to school and community. Furthermore, it determined if a significant difference existed between their levels of teaching standards competence and performance when they were grouped according to demographic variable. Finally, it examined if there is a significant relationship between teaching standards competence and performance.

\subsection{Framework of the Study}

This study was mainly anchored on the Theory of Constructivism by Jean Piaget and Lev Vygotsky and the Framework for 21st Century Learning. It was further directed to the Philippine Professional Standards for Teachers as basis of the standards for teaching competence. The Teacher Performance Evaluation of the school was also used to examine the teaching performance of the teachers.

The Theory of Constructivism represents one of the big ideas in education (Bada, 2015). It is the leading theory in teaching and learning. It was the anchor of this study because its objective was not to set standards but to look into probable areas for the improvement of teachers based on the given standards aided by their learning 
experiences (Petalla \& Madrigal, 2017). Primarily, educational reforms aimed for all students to succeed (Bada, 2015). In the light of these reforms, the students must be the focus of teaching. Gilis, et al. (2008) pointed out that constructivism has shifted in pedagogy from teacher-focused to student-focused. This is the most important contribution of constructivism in education (Bada, 2015).

Moreover, a student-centered pedagogy implies a critical role of the teachers. In a constructivist classroom, the teacher is a facilitator and guide and is primarily responsible for creating and maintaining a collaborative problem-solving environment where students are allowed to construct their own knowledge (Bada, 2015). In the process, learning approaches emerging from constructivism are designed to create a more successful classroom experience for students. Hence, this is the important role of the teachers. The teachers must focus on what learning outcomes to achieve, the design of the instruction, the activities of the students, and the related assessment strategies (Hyslop-Margison \& Strobel, 2008). Consequently, Bada (2015) identified that teachers under constructivism need to reflect on their own practices and apply these ideas into their work.

Furthermore, this is also anchored on the Framework for 21st Century Learning. This framework describes the skills, knowledge and expertise students must master to succeed in work and life. It is a blend of content knowledge, specific skills, expertise and literacies. Additionally, this enables the 21st century professional learning communities for teachers that model the kinds of classroom learning that best promote the 21st century skills and the role of teachers to teach the students (P21 Framework for 21st Century Learning, 2015).

In addition, the study is further directed to the Philippine Professional Standards for Teachers (PPST). In the $\mathrm{K}$ to 12 program of the Department of Education (DepED), this is the quality assurance instrument assessing the competence of teachers in line with the national educational standards. Through this instrument, the teacher will be able to cultivate his or her ability to identify students' particular learning styles, intelligences, strengths and weaknesses (P21 Framework for 21st Century Learning, 2015).

Finally, the study is linked to the teacher performance evaluation as an institutional instrument used to assess the performance of the teachers. The performance of teachers is vital toward the achievement of educational success, thus the need to keep the teachers abreast of the dynamic teaching standards arises. In conclusion, the theory of constructivism and teacher quality assurance instruments must work together to complete the process of seeking improvements in the 21st century teaching and learning framework. Therefore, the role of teachers becomes dynamic. And for teachers to maintain excellent professional performance under these conditions, they must assume a personal responsibility for their own performance, growth, and development (Hanif, Tariq \& Nadeem, 2011). 


\section{Basic Education Teachers \\ grouped according to sex, marital status, educational attainment, and status of employment}

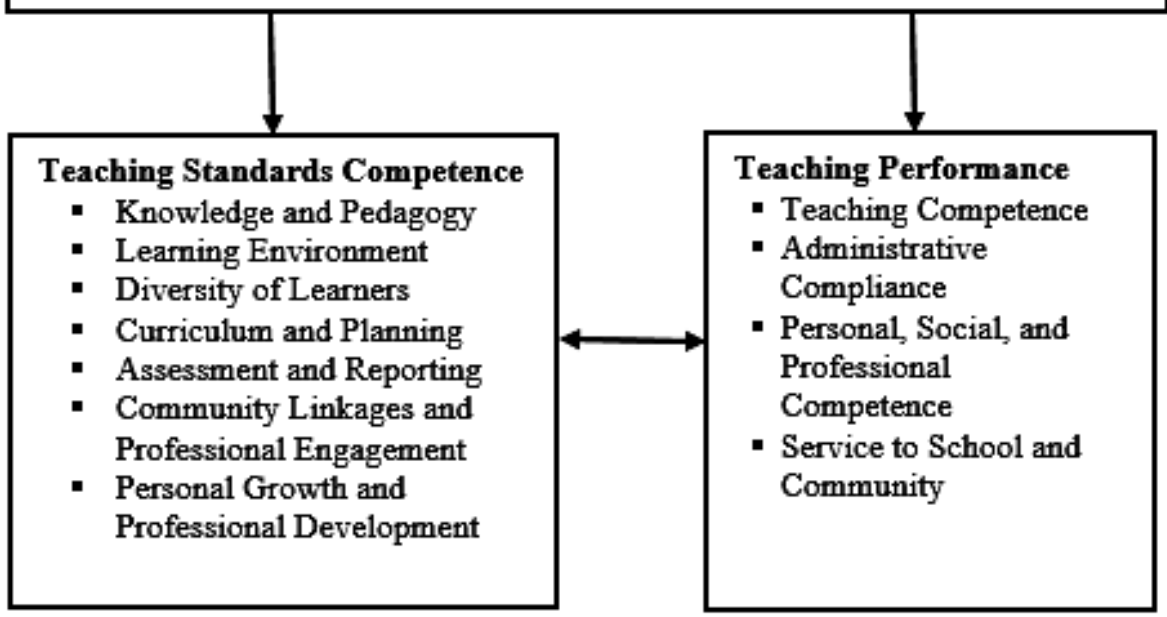

Figure 1. Conceptual Model

\subsection{Methods}

The study employed the descriptive-comparative approach to measure the levels of teaching standards competence and performance of teachers. Likewise, it was also used to determine the significant difference in the level of teaching standards competence and performance. On the other hand, a correlational research design was used to assess the relationship between teaching standards competence and performance.

The respondents of the study were the whole population of the basic education teachers of Pandan Bay Institute for the School Year 2017 - 2018. There was a total of 33 teacher-respondents composed of nine elementary school teachers, one of them was the principal, and 24 high school teachers, one of them was also the principal.

The data were gathered using two (2) standardized questionnaires, namely: the Philippine Professional Standards for Teachers (PPST) and the Teacher Performance Evaluation of the school. To measure the teaching standards competence of the teachers, the standardized survey questionnaire of the Philippine Professional Standards for Teachers (PPST) developed and adopted by the DepED was used. The Teacher Performance Evaluation tool of the diocesan school was used to rate the performance of the teachers. Reliability and validity procedures were not conducted because both instruments are standardized measurements.

In gathering the data, the approval of the Rector of the school was secured before the conduct of the study. The respondents were oriented about the purpose and scope of the study, the nature and parts of the questionnaire, and most especially, 
the affirmation of their willingness to participate in the study. The researcher secured the informed consent of the participants. They were assured of full confidentiality. The materials that contained the raw information derived from them were disposed by manual shredding.

Descriptive and inferential analyses were employed to analyze the data using appropriate statistical tools. The mean was used to determine the level of teaching standards competence and teacher performance. Meanwhile, the Mann Whitney U test and Independent samples t-test were employed to determine the significant difference in the level of teaching standards competence and teacher performance. The Pearson product moment of correlation was used to determine the correlation between teaching standards competence and teacher performance.

\subsection{Results and Discussions}

\section{Teaching standards competence}

The descriptive results showed that the level of teaching standards competence of basic education teachers of Pandan Bay Institute is "proficient" ( $M=2.02, S D=0.54)$ as rated by both the teachers $(M=2.38, S D=0.46)$ and the principals $(M=1.65, S D=0.33)$. Proficient teachers are professionally independent in the application of skills vital to the teaching and learning process. In the PPST, they belong to Career Stage 2. In terms of domains, all areas in the PPST were rated proficient.

Table 1A. Level of Teaching Standards Competence of Basic Education Teachers

\begin{tabular}{|c|c|c|c|c|c|c|c|c|c|c|c|c|}
\hline \multirow{2}{*}{$\begin{array}{l}\text { Variable } \\
\text { Respondent }\end{array}$} & \multicolumn{3}{|c|}{$\begin{array}{l}\text { Content } \\
\text { Knowledge } \\
\text { and Pedagogy }\end{array}$} & \multicolumn{3}{|c|}{$\begin{array}{l}\text { Learning } \\
\text { Environment }\end{array}$} & \multicolumn{3}{|c|}{$\begin{array}{l}\text { Diversity of } \\
\text { Learners }\end{array}$} & \multicolumn{3}{|c|}{$\begin{array}{l}\text { Curriculum and } \\
\text { Planning }\end{array}$} \\
\hline & $\mathrm{M}$ & SD & Int & $M$ & SD & Int & $M$ & SD & Int & $\mathrm{M}$ & SD & Int \\
\hline $\begin{array}{l}\text { Teachers } \\
(n=33)\end{array}$ & 2.30 & 0.45 & $P$ & 2.57 & 0.51 & $\mathrm{HP}$ & 2.27 & 0.50 & $P$ & 2.32 & 0.51 & $P$ \\
\hline $\begin{array}{l}\text { Principals } \\
(n=33)\end{array}$ & 1.71 & 0.38 & $\mathrm{P}$ & 1.68 & 0.38 & $\mathrm{P}$ & 1.15 & 0.20 & B & 1.76 & 0.46 & $\mathrm{P}$ \\
\hline As a Whole & 2.01 & 0.51 & $\mathrm{P}$ & 1.68 & 0.38 & $\mathrm{P}$ & 1.71 & 0.68 & $P$ & 2.04 & 0.56 & $\mathrm{P}$ \\
\hline
\end{tabular}

Note: Int=Interpretation; P=Proficient; HP=Highly Proficient; $\mathrm{B}=$ Beginning

The area of personal growth and professional development got the highest rating. This result manifests that teachers of a diocesan school practice high regard for the teaching profession. They keep themselves abreast of the new and requisite knowledge, skills and attitudes as expected from them (Castleberry, 2010). On the contrary, the area of diversity of learners got the lowest rating. This result indicated that there is a need to focus on the area of diversity of learners. At the diocesan school, there are facilities intended for diverse learners but programs for learner diversity are not well-articulated in the curriculum. Hall, MacDonald and Smolen (1995) mentioned that as early as 1990s when teacher education prepared teachers to work in schools responsive to social and economic shifts. This idea indicates that the school and the teachers must be prepared to respond to the needs of diverse learners. 
Table 1B. Level of Teaching Standard Competence of Basic Education Teachers

\begin{tabular}{|c|c|c|c|c|c|c|c|c|c|c|c|c|}
\hline \multirow[b]{2}{*}{ Respondent } & \multicolumn{3}{|c|}{$\begin{array}{l}\text { Assessment } \\
\text { and Reporting }\end{array}$} & \multicolumn{3}{|c|}{$\begin{array}{l}\text { Community } \\
\text { Linkages and } \\
\text { Professional } \\
\text { Engagement }\end{array}$} & \multicolumn{3}{|c|}{$\begin{array}{l}\text { Personal Growth } \\
\text { and Professional } \\
\text { Development }\end{array}$} & \multicolumn{3}{|c|}{$\begin{array}{l}\text { Teaching } \\
\text { Standards } \\
\text { Competence }\end{array}$} \\
\hline & $M$ & SD & Int & $M$ & SD & Int & $M$ & SD & Int & $M$ & SD & Int \\
\hline $\begin{array}{l}\text { Teachers } \\
(n=33)\end{array}$ & 2.31 & 0.54 & $P$ & 2.39 & 0.56 & $P$ & 2.52 & 0.58 & HP & 2.38 & 0.46 & $P$ \\
\hline $\begin{array}{l}\text { Principals } \\
(n=33)\end{array}$ & 1.57 & 0.34 & $P$ & 1.83 & 0.51 & $P$ & 1.84 & 0.48 & B & 1.65 & 0.33 & $P$ \\
\hline As a Whole & 1.94 & 0.58 & $\mathrm{P}$ & 2.11 & 0.60 & $\mathrm{P}$ & 2.18 & 0.63 & $\mathrm{P}$ & 2.02 & 0.54 & $\mathrm{P}$ \\
\hline
\end{tabular}

Note: Int=Interpretation; P=Proficient; $\mathrm{HP}=$ Highly Proficient; B=Beginning

Therefore, training and other programs pertaining to the establishment of learning environment that are responsive to learner diversity must be provided. In terms of variables, master's degree teachers got the highest rating. This result emphasized the role of continuous study and faculty development as an important consideration for improving teaching competence especially on the standards. However, probationary teachers got the lowest rating as they rated themselves "proficient". This situation can be described that beginning teachers face a high degree of instructional performance problems (Cho \& Dae-Bong, 2014).

\section{Teaching performance}

The teaching performance of basic education teachers of Pandan Bay Institute as a whole as assessed by both the teachers $(M=3.42, S D=0.46)$ and the principals $(M=3.43$, $\mathrm{SD}=0.57)$ is "satisfactory" $(\mathrm{M}=3.43, \mathrm{SD}=0.51)$. The result is satisfactory, but it still implies that thereisaneed toimproveinordertoadvancetohighorveryhighteaching performance. Harrison (2002) contended that in order to get through with an objective measure of teaching performance, a continued teaching evaluation should be conducted regularly.

Table 2. Level of Teaching Performance of Basic Education Teachers

\begin{tabular}{|c|c|c|c|c|c|c|c|c|c|c|}
\hline \multirow{2}{*}{$\begin{array}{l}\text { Variable } \\
\text { Respondent }\end{array}$} & \multicolumn{2}{|c|}{$\begin{array}{l}\text { Teaching } \\
\text { Competence }\end{array}$} & \multicolumn{2}{|c|}{$\begin{array}{l}\text { Administrative } \\
\text { Compliance }\end{array}$} & \multicolumn{2}{|c|}{$\begin{array}{l}\text { Personal, } \\
\text { Social, and } \\
\text { Professional } \\
\text { Competence }\end{array}$} & \multicolumn{2}{|c|}{$\begin{array}{l}\text { Service to } \\
\text { School and } \\
\text { Community }\end{array}$} & \multicolumn{2}{|c|}{ Performance } \\
\hline & $M$ & SD & $M$ & SD & $\mathrm{M}$ & SD & $M$ & SD & M & SD \\
\hline $\begin{array}{l}\text { Teachers } \\
(n=33)\end{array}$ & 3.41 & 0.52 & 3.22 & 0.62 & 3.56 & 0.50 & 3.56 & 0.54 & 3.42 & 0.46 \\
\hline Interpretation & \multicolumn{2}{|c|}{ Satisfactory } & \multicolumn{2}{|c|}{ Satisfactory } & \multicolumn{2}{|l|}{ High } & \multicolumn{2}{|l|}{ High } & \multicolumn{2}{|c|}{ Satisfactory } \\
\hline $\begin{array}{l}\text { Principals } \\
(n=33)\end{array}$ & 3.48 & 0.69 & 3.38 & 0.77 & 3.42 & 0.70 & 3.42 & 0.55 & 3.43 & 0.57 \\
\hline Interpretation & \multicolumn{2}{|c|}{ Satisfactory } & \multicolumn{2}{|c|}{ Satisfactory } & \multicolumn{2}{|c|}{ Satisfactory } & \multicolumn{2}{|c|}{ Satisfactory } & \multicolumn{2}{|c|}{ Satisfactory } \\
\hline As a Whole & 3.45 & 0.61 & 3.30 & 0.70 & 3.49 & 0.61 & 3.49 & 0.54 & 3.43 & 0.51 \\
\hline Interpretation & \multicolumn{2}{|c|}{ Satisfactory } & \multicolumn{2}{|c|}{ Satisfactory } & \multicolumn{2}{|c|}{ Satisfactory } & \multicolumn{2}{|c|}{ Satisfactory } & \multicolumn{2}{|c|}{ Satisfactory } \\
\hline
\end{tabular}


Through regular and continued evaluation, the progress in the performance of teachers can be tracked properly. Relative to the teaching performance, personal, social, and professional competence and service to school and community got the highest rating.

However, the area of administrative compliance got the lowest rating as assessed by both teachers and principals. This could be because a number of teachers in the diocesan school really have difficulty in meeting the requirements of submission, punctuality, and attendance. Besides, Hawes (2015) correspondingly stated that standard-based education focuses more on assessment and reporting practices which can be the reason why teachers were rated low in administrative compliance because of the paper works on assessment and reporting. Likewise, the attitude and habit of work of teachers must also be considered because learning is both cognitive and situative (Yakhlef, 2010 as cited by Dobson, 2013). In terms of variables, master's degree teachers displayed high performance for getting the highest rating from the assessment of both the teacher and the principal. This result indicated the high commitment of master's degree teachers to the profession. The result on the level of teaching performance with the highest rating is similar to the result of the level of teaching standards competence. Meanwhile, probationary teachers scored lowest in the teaching performance.

\section{Difference in teaching standards competence}

The inferential results present no significant difference in the teaching standards competence as assessed by teachers and principals using the Mann Whitney $U$ test and Independent samples t-test. Using this result, the teachers found out that certain variables used in this study did not determine the differences in their competence when it comes to standards. However, there was a significant difference when teachers were grouped according to status of employment except in the area of personal growth and professional development. In the area of personal growth and professional development, there was also a significant difference when teachers were grouped according to educational attainment. The assessment of the principals showed a very significant difference in the teaching standards competence in terms of status of employment. Regular teachers are expected to perform better while probationary teachers need to gain more inspiration from experience.

\section{Difference in teaching performance}

The result also showed no significant difference in the teaching performance as assessed by the teachers and principals using the Mann Whitney $U$ test and Independent samples t-test. This result of the study shows that sex, marital status, educational attainment, and status of employment are not determinant to the performance of the teachers. However, in the assessment of the teachers, a significant difference was found in the area of personal, social, and professional competence when teachers were grouped according to status of employment. Also, in the area of service to school and community, there was a significant difference when teachers were grouped according to educational attainment. As assessed by the principals, there was a significant difference 
in the area of service to school and community when teachers were grouped according to status of employment.

In the study of Shafi and Sultan (2014), educational qualification of teachers affects students' performance. The study of Shafi and Sultan (2014) supports this finding that there was a significant difference in the area of service to school and community when they were grouped according to educational attainment. Teachers with high qualification are more dedicated in terms of service to school and community. Same result was based on the status of employment whether teachers are probationary or regular. In the case of probationary teachers, it is understood and given because they are experiencing difficulties like facing multiple unfamiliar responsibilities and challenges (Cho \& Dae-Bong, 2004). Comparably, this result is in congruence to the level of teaching performance of master's degree teachers which is high compared to the bachelor's degree teachers which is satisfactory.

\section{Relationship between teaching standards competence and performance}

For the correlational result, the findings in Table 3 revealed that there is a significant relationship between teaching standards competence and performance $[r$ (64) $=0.457, p=0.000]$ analyzed using Pearson product moment of correlation (PPM). The findings revealed that teaching standards competence is associated with the teaching performance of the basic education teachers of the diocesan school. This result establishes the connection between competence which includes skills, knowledge and behaviors and performance which are indicated as the specific outcomes of competence. The findings of this study negate or contradict the findings of the study conducted by Petalla and Madrigal (2017) that there is no significant relationship between teaching standards competence and efficiency performance. The results are contradicting in the sense that the context and the environment of the teachers where the study was conducted was totally different. Petalla and Madrigal (2017) conducted their study in a university where teacher-respondents were exposed to trainings and other professional development while this study was conducted in an average catholic school with limited provision of professional trainings, and some teachers were neophytes in the profession.

Table 3. Significant Relationship Between Teaching Standards Competence and Performance

\begin{tabular}{lccc}
\hline Variable & $\mathbf{r}$ & $\mathbf{d f}$ & $\mathbf{p}$ \\
Teaching Standards Competence x Performance & $0.457^{*}$ & 64 & 0.000 \\
\hline Note: the correlation is significant when $\mathrm{p} \leq 0.05$ & & &
\end{tabular}

The study presented that the assessment levels of competence and performance of basic education teachers are proficient and satisfactory. In the pursuit of quality, it can be noted that there is still room for continuous improvement to advance to the higher level of competence and performance. Thus, quality teaching through quality teachers must be realized through the provision of enough trainings and professional assistance to teachers coupled with a regular and continued evaluation of performance. Attitude and habit of teachers toward work must also be assessed. The teachers must document their practices and commit themselves for continuous improvement in the weak areas. The strength and expertise of master teachers and other competent teachers can be utilized in mentoring new teachers through the creation of professional learning 
communities or learning action cells. The school has to give attention to programs in the curriculum that respond to the diversity of learners considering other factors like cultural, socio-economic, disabilities, giftedness, and those learners from indigenous groups.

\subsection{Conclusion}

The teaching standards competence of teachers is determined by their knowledge, skills, and attitudes through their participation in the different in-service trainings and programs. However, the teaching performance is mostly affected by habit of work and experience in the profession. The competence of the teachers in the standards associates or influences their teaching performance. The teachers can continuously monitor their own progress in the teaching standards to help them meet the required competence toward improving their teaching performance. The importance of personal growth and development like seeking further studies and pursuing master's degree and other professional courses is a prime concern that the school has to embark on to maintain teacher quality. The school may opt to invest resources on the training and development of the teachers to further bring out the desired outcomes. Master teachers and probationary teachers must closely work in harmony and collaboration since it was found out that it is effective to achieve educational success in developing best pedagogical practices.

\subsection{Recommendations}

Based on the findings of this study, the researcher recommends the following plan of actions:

Relative to teaching competence of teachers, the school must create a functional and well-articulated faculty development program that is geared toward the continuous development of the teachers. The board of trustees can be provided with a concrete faculty development program of the school which they can use as basis in appropriating budget intended for this purpose. Teachers should attend and actively participate in the different school-based or sponsored training and enhancement programs. The administration should encourage the teachers to professionally upgrade themselves by pursuing master's and doctorate studies. Probationary teachers should be provided with induction programs that will prepare them for the real tasks.

With regard to teaching performance, the school administrators may consider an evaluation instrument that is aligned with the PPST; conduct close and regular monitoring and supervision of the teachers; and provide a variety and adequate opportunities for teachers to collaborate with one another, particularly the master's and competent teachers with the probationary teachers. Also, a systematic ranking can be created to put in place the status of teachers. The basic education teachers should be provided with a system to assess their own teaching standards competence and performance through annual updating and monitoring in the PPST and performance evaluation. The school has to establish and strengthen connections with other stakeholders like the alumni, parents, and government leaders.

Future researchers are also encouraged to conduct a similar study on the competence and performance of the teachers by looking further into this instrument 
aligned with PPST and on learner diversity so that the findings would rectify the result this study has found.

\section{REFERENCES}

Bada, S. O. (2015). Constructivism learning theory: A paradigm for teaching and Learning. IOSR Journal of Research \& Method in Education. Retrieved from www.iosrjournals.org DOI: 10.979 0/738805616670 www.iosrjournals.org 66

Beck, C., Hart, D., \& Kosnik, C. (2002). The Teaching Standards Movement and Current Teaching Practices. Canadian Journal of Education; 2002; 27, 2/3; ProQuest pg. 175.

Castleberry, E. A. (2010). Influences of professional development on teachers and teacher retention: Perceptions of teachers and professional development administrators (Order No. 3425891). Available from Education Database. (762235169). Retrieved from https://search.pro quest.com/ docview/762235169?accountid=34542

Centre of Study for Policies and Practices in Education (CEPPE). (2013). "Learning Standards, Teaching Standards and Standards for School Principals: A Comparative Study," OECD Education Working Papers, No. 99, OECD Publishing. Retrieved from: http://dx.doi.org/10.1787/5k3tsiatp90v-en

Cho, D., \& Dae-Bong Kwon. (2004). Determining the content of induction programs: To improve instructional performance: A case in Seoul, Korea. Alberta Journal of Educational Research, 50(2), 189-199. Retrieved from https://search. proquest.com/docview/ 228592403 ? accountid=34542

DepED. (2012). DO 31, s. 2012 - Policy Guidelines on the Implementation of Grades 1 to 10 of the $K$ to 12 basic Education Curriculum (BEC) Effective School Year 2012-2013. Retrieved from http://www.deped. gov.ph/ orders/do-31-s-2012

DepED. (2009). DO 32, s. 2009 - National Adoptation and Implementation of NCBTS-TSNA and IPPD for Teachers, and Integration of Its System Operations in the Overall Program for Continuing Teacher Capacity Building. Retrieved November 17, 2017 from http://www.deped.gov. ph/sites/default/ files/order/2009/DO_s2009_32.pdf

DepED. (2017). DO 42, s. 2017 - National Adoptation and Implementation of the Philippine Professional Standards for Teachers. Retrieved October 18, 2017 from http://www.deped.gov.ph/ orders/do42-s-2017

Dobson, E. E. (2013). Examining the impact of early field experiences on teacher candidate readiness (Order No. 3610779). Available from Education Database. (1500831604). Retrieved from https://search. proquest.com/docview $/ 1500831604$ ?accountid $=34542$

“Education for All 2015 National Review Report: Philippines" (2014). Retrieved from http://unesdoc.unesco. org /images/0023/002303/230331e.pdf

Gilis, A., Clement, M., Laga, L., \& Pauwels, P. (2008). Establishing a competence profile for the role of studentcentred teachers in higher education in belgium. Research in Higher Education, 49(6), 531-554. doi:http://dx.doi.org/10.1007/s11162-008-9086-7

Hall, S. C., MacDonald, S., \& Smolen, L. (1995). Preparing Preservice Teachers for Diversity in Learners. Journal of Teacher Education, Vol. 46, Issue 4, p. 295-303, Retrieved on February 18, 2017 from https:// doi.org/10.1177\%2F0022487195046004008 
Hanif, R., Tariq, S., \& Nadeem, M. (2011). Personal and job-related predictors of teacher stress and job performance among school teachers. Pakistan Journal of Commerce and Social Sciences, 5(2), 319-329.

Hargrove, T., Walker, B. L., Huber, R. A., Corrigan, S. Z., \& Moore, C. (2004). No teacher left behind: Supporting teachers as they implement standards-based reform in a test-based education environment. Education, 124(3), 567.

Harrison, J. E. (2002). The quality of university teaching: Faculty performance and accountability. A literature review. CSSHE Professional File, (21), 3-20. Retrieved from https://search. proquest.com/ docview/203474424?accountid $=34542$

Hawes, K. M. (2015). An examination of standards-based education relative to research-based practices in instruction and assessment (Order No. 3688510). Available from Education Database. (1674246936). Retrieved from https://search.proquest.com/docview/ 167424 6936?accountid=34542

Hyslop-Margison, E., \& Strobel, J. (2008). Constructivism and Education: Misunderstandings and Pedagogical Implications. The Teacher Educator, 43(1), 72-86. Retrieved from https://search.proquest.com/ docview $/ 220636020$ ? accountid $=34542$

Lyall, K.C. (1997). Once and future partners: The state and its university. Innovative Education, 22(1).

Petalla, M. B. \& Madrigal, D. V. (2017). Teaching standards competence and efficiency performance of the basic education teachers. University of Negros Occidental-Recoletos, Bacolod City, Philippines. Journal of Institutional Research in South East Asia - Vol. 15 No.3 Dec 2017

Philippine Professional Standards for Teachers. (2017). Department of Education-Teacher Education Council. Republic of the Philippines.

P21 Framework for 21st Century Learning. (2015). Retrieved from www.p21.org.

Rasool, G., Mahboob, U., Sajid, M., \& Ahmad, S. (2017). Characteristics of effective teaching: a survey on teacher's perceptions. Pakistan Oral \& Dental Journal, 37(1) Retrieved from https://search. proquest.com/docview $/ 1891291525$ ?accountid $=34542$

Shafi, M., \& Sultan, S. (2014). Impact of perceived teachers' competence on students' performance: Mediating and moderating role of class environment. Journal of Educational Research, 17(2), 117-130. Retrieved from https://search. proquest.com/docview/ 1786829285 ?accountid=34542

Soepriyatna (2012). Malaysian Journal of ELT Research, Vol. 8(2), pp. 38-49.

Sturgis, C., Rath, B., Weissstien, E. \& Patrick, S. (2010). Clearing the path: Creating innovation space for serving over-age, under-credited students in competency-based pathways. Retrieved from www.inacol. org

Teacher Performance Evaluation. Pandan Bay Institute., Pandan, Antique

University of Mississippi. (1995). Enhancing teaching effectiveness. Report of Task Force I: Teaching. University, MS: Task Force I, University of Mississippi. Retrieved from http://www.olemiss. edu/

Xu, X., Grant, L. W., \& Ward, T. J. (2016). Validation of a statewide teacher evaluation system. National Association of Secondary School Principals. NASSP Bulletin, 100(4), 203-222. 
Bada, S. O. (2015). Constructivism learning theory: A paradigm for teaching and Learning. IOSR Journal of Research \& Method in Education. Retrieved from www.iosrjournals.org DOI: 10.979 0/738805616670 www.iosrjournals.org 66

Beck, C., Hart, D., \& Kosnik, C. (2002). The Teaching Standards Movement and Current Teaching Practices. Canadian Journal of Education; 2002; 27, 2/3; ProQuest pg. 175.

Castleberry, E. A. (2010). Influences of professional development on teachers and teacher retention: Perceptions of teachers and professional development administrators (Order No. 3425891). Available from Education Database. (762235169). Retrieved from https://search.pro quest.com/ docview/762235169?accountid $=34542$

Centre of Study for Policies and Practices in Education (CEPPE). (2013). "Learning Standards, Teaching Standards and Standards for School Principals: A Comparative Study," OECD Education Working Papers, No. 99, OECD Publishing. Retrieved from: http://dx.doi.org/10.1787/5k3tsiatp90ven

Cho, D., \& Dae-Bong Kwon. (2004). Determining the content of induction programs: To improve instructional performance: A case in Seoul, Korea. Alberta Journal of Educational Research, 50(2), 189-199. Retrieved from https://search.proquest.com/docview/ 228592403 ? accountid=34542

DepED. (2012). DO 31, s. 2012 - Policy Guidelines on the Implementation of Grades 1 to 10 of the $K$ to 12 basic Education Curriculum (BEC) Effective School Year 2012-2013. Retrieved from http://www.deped. gov.ph/ orders/do-31-s-2012

DepED. (2009). DO 32, s. 2009 - National Adoptation and Implementation of NCBTS-TSNA and IPPD for Teachers, and Integration of Its System Operations in the Overall Program for Continuing Teacher Capacity Building. Retrieved November 17, 2017 from http://www.deped.gov. ph/sites/default/ files/order/2009/DO_s2009_32.pdf

DepED. (2017). DO 42, s. 2017 - National Adoptation and Implementation of the Philippine Professional Standards for Teachers. Retrieved October 18, 2017 from http://www.deped.gov.ph/ orders/do42-s-2017

Dobson, E. E. (2013). Examining the impact of early field experiences on teacher candidate readiness (Order No. 3610779). Available from Education Database. (1500831604). Retrieved from https://search. proquest.com/docview/1500831604?accountid=34542

"Education for All 2015 National Review Report: Philippines" (2014). Retrieved from http://unesdoc.unesco.org /images/0023/002303/230331e.pdf

Gilis, A., Clement, M., Laga, L., \& Pauwels, P. (2008). Establishing a competence profile for the role of studentcentred teachers in higher education in belgium. Research in Higher Education, 49(6), 531-554. doi:http://dx.doi.org/10.1007/s11162-008-9086-7

Hall, S. C., MacDonald, S., \& Smolen, L. (1995). Preparing Preservice Teachers for Diversity in Learners. Journal of Teacher Education, Vol. 46, Issue 4, p. 295-303, Retrieved on February 18, 2017 from https://doi.org/10.1177\%2F0022487195046004008

Hanif, R., Tariq, S., \& Nadeem, M. (2011). Personal and job-related predictors of teacher stress and job performance among school teachers. Pakistan Journal of Commerce and Social Sciences, 5(2), 319-329.

Hargrove, T., Walker, B. L., Huber, R. A., Corrigan, S. Z., \& Moore, C. (2004). No teacher left behind: Supporting teachers as they implement standards-based reform in a test-based education environment. Education, 124(3), 567. 
Harrison, J. E. (2002). The quality of university teaching: Faculty performance and accountability. A literature review. CSSHE Professional File, (21), 3-20. Retrieved from https://search. proquest. com/docview/203474424?accountid=34542

Hawes, K. M. (2015). An examination of standards-based education relative to research-based practices in instruction and assessment (Order No. 3688510). Available from Education Database. (1674246936). Retrieved from https://search.proquest.com/docview/ 167424 6936 ? accountid $=34542$

Hyslop-Margison, E., \& Strobel, J. (2008). Constructivism and Education: Misunderstandings and Pedagogical Implications. The Teacher Educator, 43(1), 72-86. Retrieved from https://search.proquest.com/docview/2206360 20? accountid=34542

Lyall, K.C. (1997). Once and future partners: The state and its university. Innovative Education, 22(1).

Petalla, M. B. \& Madrigal, D. V. (2017). Teaching standards competence and efficiency performance of the basic education teachers. University of Negros Occidental-Recoletos, Bacolod City, Philippines. Journal of Institutional Research in South East Asia - Vol. 15 No.3 Dec 2017

Philippine Professional Standards for Teachers. (2017). Department of Education-Teacher Education Council. Republic of the Philippines.

P21 Framework for $21^{\text {st }}$ Century Learning. (2015). Retrieved from www.p21.org.

Rasool, G., Mahboob, U., Sajid, M., \& Ahmad, S. (2017). Characteristics of effective teaching: a survey on teacher's perceptions. Pakistan Oral \& Dental Journal, 37(1) Retrieved from https://search. proquest.com/docview/1891291525?accountid=34542

Shafi, M., \& Sultan, S. (2014). Impact of perceived teachers' competence on students' performance: Mediating and moderating role of class environment. .Journal of Educational Research, 17(2), 117 130. Retrieved from https://search. proquest.com/docview/ 1786829285 ?accountid=34542

Soepriyatna (2012). Malaysian Journal of ELT Research, Vol. 8(2), pp. 38-49.

Sturgis, C., Rath, B., Weissstien, E. \& Patrick, S. (2010). Clearing the path: Creating innovation space for serving over-age, under-credited students in competency-based pathways. Retrieved from www. inacol.org

Teacher Performance Evaluation. Pandan Bay Institute., Pandan, Antique

University of Mississippi. (1995). Enhancing teaching effectiveness. Report of Task Force I: Teaching. University, MS: Task Force I, University of Mississippi. Retrieved from http://www.olemiss. edu/

Xu, X., Grant, L. W., \& Ward, T. J. (2016). Validation of a statewide teacher evaluation system. National Association of Secondary School Principals. NASSP Bulletin, 100(4), 203-222. 